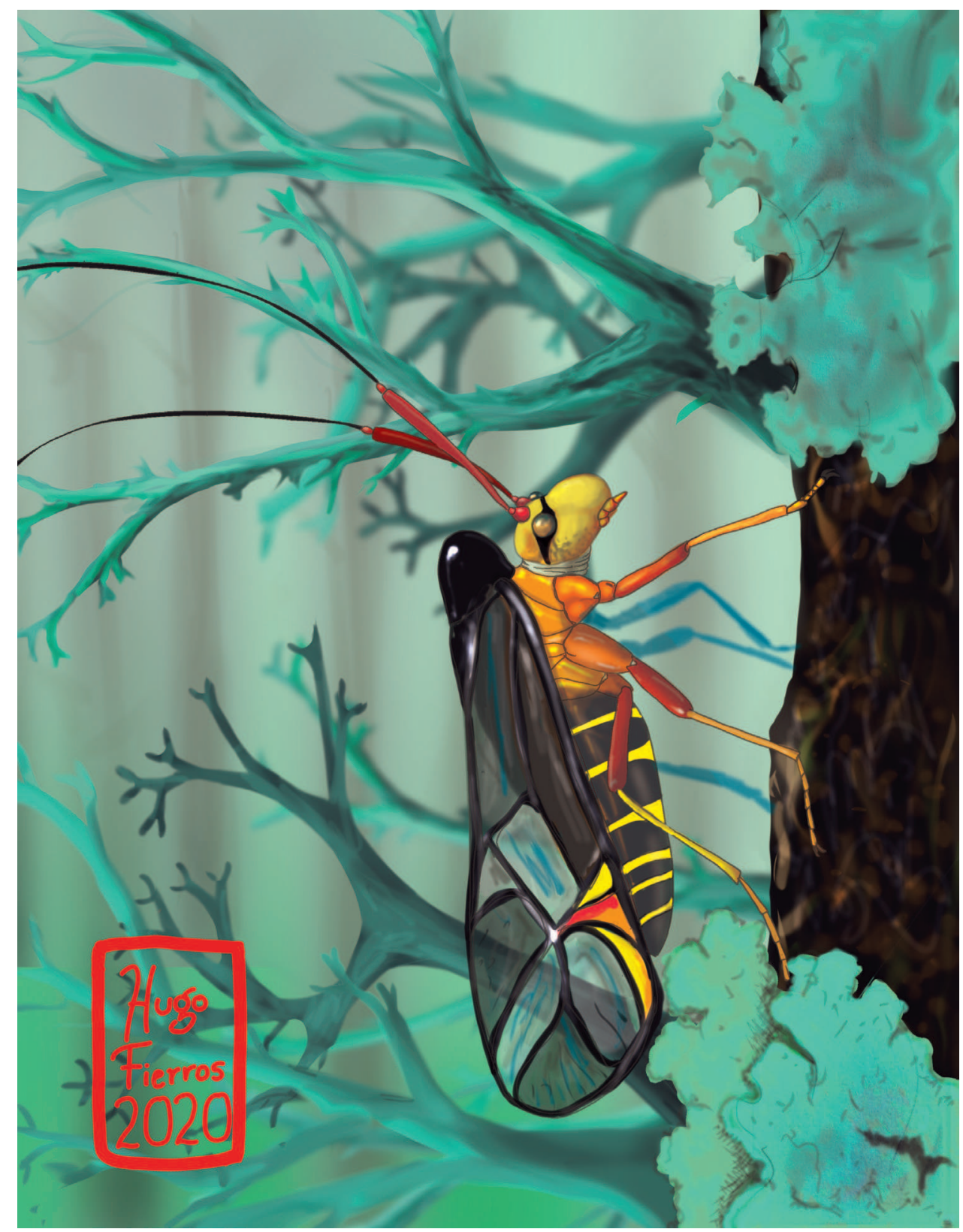

Dugesiana, Año 27, No. 2, julio 2020-diciembre 2020 segundo semestre de 2020), es una publicación semestral, editada por la Universidad de Guadalajara, a través del Centro de Estudios en Zoología, por el Centro Universitario de Ciencias Biológicas y Agropecuarias. Camino Ramón Padilla Sánchez \# 2100, Nextipac, Zapopan, Jalisco, Tel. 37771150 ext. 33218, http://148.202.248.171/dugesiana/index.php/DUG/index, glenusmx@gmail.com. Editor responsable: José Luis Navarrete-Heredia. Reserva de Derechos al Uso Exclusivo 04-2009-062310115100203, ISSN: 2007-9133, otorgados por el Instituto Nacional del Derecho de Autor. Responsable de la última actualización de este número: José Luis Navarrete-Heredia, Editor y Ana Laura González-Hernández, Asistente Editorial. Fecha de la última modificación 1 de julio 2020, con un tiraje de un ejemplar.

Las opiniones expresadas por los autores no necesariamente reflejan la postura del editor de la publicación.

Queda estrictamente prohibida la reproducción total o parcial de los contenidos e imágenes de la publicación sin previa autorización de la Universidad de Guadalajara. 


\title{
Garcialdretiella, a new genus of Lachesillidae (Psocodea: 'Psocoptera': Eolachesillinae: Gra- phocaeciliini) from Munchique National Natural Park, Colombia
}

\section{Garcialdretiella, un género nuevo de Lachesillidae (Psocodea: Eolachesillinae: Graphocaeciliini) del Par- que Nacional Natural Munchique, Colombia}

\author{
Ranulfo González-Obando ${ }^{1}$, Stephania Sandoval-Arango ${ }^{2}$ y Nancy Carrejo-Gironza ${ }^{1}$ \\ ${ }^{1}$ Departamento de Biología, Facultad de Ciencias Naturales y Exactas, Universidad del Valle, Santiago de Cali, \\ Colombia. E-mail: ranulfo.gonzalez@correounivalle.edu.co; nancy.carrejo@correounivalle.edu.co; ${ }^{2}$ Department \\ of Entomology, Pennsylvania State University, University Park, PA 16802. E-mail: s.sandoval793@gmail.com
}

\begin{abstract}
A new genus and species of Lachesillidae from Munchique National Natural Park, Cauca, Colombia, is here described and illustrated. The genus belongs to the tribe Graphocaeciliini (Eolachesillinae). It is related to Acantholachesilla Garcia Aldrete, Saenz \& Gonzalez (2014), Dagualachesilla Garcia Aldrete, Gonzalez \& Carrejo (2013) and Dagualachesilloides Garcia Aldrete, Gonzalez \& Carrejo (2013), differing from them in the male clunial projection and phallosome. The types are deposited in the Entomological Museum, Universidad del Valle (MUSENUV), Santiago de Cali, Colombia.

Key words: Barklice, neotropics, National Parks, taxonomy.
\end{abstract}

\section{RESUMEN}

Se describe e ilustra un nuevo género y especie de Lachesillidae, del Parque Nacional Natural Munchique, Cauca, Colombia. Pertenece a la tribu Graphocaeciliini (Eolachesillinae) y está relacionado con Acantholachesilla García Aldrete, Saenz \& González (2014), Dagualachesilla García Aldrete, González \& Carrejo (2013) y Dagualachesilloides García Aldrete, González \& Carrejo (2013), diferenciándose de ellos en la proyección clunial de los machos y en detalles del falosoma. Los tipos están depositados en el Museo Entomológico, Universidad del Valle (MUSENUV), Santiago de Cali, Colombia.

Palabras clave: Neotrópico, Parques Nacionales, piojos de la corteza, taxonomía.

The tribe Graphocaeciliini (Lachesillidae, subfamily Eolachesillinae), includes 14 Neotropical genera (Mockford \& Sullivan, 1986; Garcia Aldrete \& Mockford, 2011; García Aldrete, 2012; Garcia Aldrete et al. 2012; 2013 a, b; 2014). As a partial result of the project "Revisión Taxonómica y Endemismos de los Psócidos (Psocodea: 'Psocoptera') de Parques Naturales de Colombia", we found five specimens of a new genus collected in Munchique National Natural Park, in Cauca. The new genus is related to $D a$ gualachesilla Garcia Aldrete, Gonzalez \& Carrejo (2013), Dagualachesilloides Garcia Aldrete, Gonzalez \& Carrejo (2013) and Acantholachesilla Garcia Aldrete, Saenz \& Gonzalez (2014). The purpose of this work is to describe and illustrate the new genus, and to establish its relationships with the related genera of Graphoceciliini.

\section{MATERIAL AND METHODS}

Five males were available for study. The specimens were collected at the Munchique National Natural Park, Cauca department, Colombia. Two males were dissected in $80 \%$ ethanol, and their parts (head, right wings and legs, and genitalia), were mounted on slides in Canada balsam. Color was recorded by placing whole specimens, before dissection, under a microscope illuminated with cold white light, at 50X. Parts on the slides were measured, following standard procedures, and the illustrations were made from digital photographs, taken with a Canon T3i camera and Helicon Focus program, processed in a vector graphics editor CorelDraw.

Abbreviations of parts measured are as follows: FW and HW: lengths of right fore- and hind- wings, L: forewing length; W: forewing width; lp: pterostigma length; wp: pterostigma width; 1: hindwing length; w: hindwing width; al: areola postica length; ah: areola postica height; F, T, tl and t2: lengths of femur, tibia and tarsomeres 1 and 2 of right hind leg, respectively, ctt1: number of ctenidobothria on $\mathrm{t} 1, \mathrm{Mx} 2, \mathrm{Mx} 4$ : length of second and fourth segment of right maxillary palpus, f1...fn: lengths of flagellomeres 1 ...n of right antenna, IO, D and d, respectively: minimum distance between compound eyes, antero-posterior diameter and transverse diameter of right compound eye, all in dorsal view of head. Ratios of eyes and wings also were calculated: PO: d/D; IO/d; L/W; 1/w; lp/wp; al/ah. The photographs were taken with a digital camera Canon T5i and Helicon Focus program. The illustrations were processed in Clip Studio Paint vector graphics editor program. The specimens studied are deposited in the Entomological Museum, Universidad del Valle (MUSENUV), Santiago de Cali, Colombia.

To assess the relationships of the new genus with the three related genera, a phylogenetic analysis was conducted in TNT and Winclada. The basic data matrix for eight taxa was built with 26 discrete characters using MESQUITE (Maddison \& Maddison, 2019) (Table 1). Ectopsocus andinus Saenz, González \& Garcia Aldrete, Waoraniella andina Saenz, Gonzalez \& Garcia Aldrete and Hemicaecilius 
smithersi Garcia Aldrete, Gonzalez \& Carrejo, were chosen as outgroups; the character states were unweighted and treated as unordered, those considered ambiguous or absent were coded as (?). The option implicit enumeration in TNT (Goloboff et al., 2008), was utilized. The nodes were supported on TNT by means of symmetric resampling (Felsentein, 1985), with 5000 pseudoreplicas. The species included in the ingroup are: Acantholachesilla saltoensis Garcia Aldrete, Saenz \& Gonzalez, Dagualachesilla queremalensis Garcia Aldrete, Gonzalez \& Carrejo, D. anchicayaensis Garcia Aldrete, Gonzalez \& Carrejo, Dagualachesilloides caliensis Garcia Aldrete, Gonzalez \& Carrejo, Garcialdretiella munchiquensis n. sp., Ectopsocus andinus Saenz, González \& Garcia Aldrete (2014), Waoraniella andina Saenz, Gonzalez \& Garcia Aldrete (2018) and Hemicaecilius smithersi Garcia Aldrete, Gonzalez and Carrejo (2012).

The characters used in the phylogenetic analysis are as follows:

0 . Ocelli $($ absent $=0$, present $=1)$

1. Epistomal suture (dorsally developed $=0$, present only laterally $=1$ )

2. Macrosetae in forewing (absent $=0$, one row present $=$ 1 , two rows present $=2$ )

3. Veins Rs and M of forewing joined by a crossvein (absent $=0$, present $=1$ )

4. Macrosetae in the costal margin of forewing (one row present $=0$, two rows present $=1$ )

5. Setae on membrane of pterostigma (absent $=0$, present $=1$ )

6. Clunial process over the area of the epiproct (absent $=0$, slightly projected $=1$, strongly projected $=2$ )

7. Clunial process over the area of the epiproct distally (as wide as base $=0$, wider than base $=1$, narrower than base $=2$ )

8. Dorsal spines on clunial process $($ absent $=0$, present $=$ 1)

9. Posterior border of the clunial process over the area of the epiproct $($ convex $=0$, straight $=1$, concave $=2$ )

10. Clunial process over the area of the epiproct with serrated posterior edge $($ absent $=0$, present $=1)$

11. External parameres with elongated basal processes (ab$\operatorname{sent}=0$, present $=1$ )

12. Male aedeagus and external parameres (well developed $=0$, reduced or fused $=1$ )

13. Male phallosome with phallobase (closed, heavily sclerotized $=0$, membranous, not heavily sclerotized $=1$ )

14. Endophallic sclerites (small or poorly developed $=0$, well developed $=1$ )

15. Endophallus with denticles (absent $=0$, present $=1$ )

16. Endophallic sclerites fused in a papillar structure (absent $=0$, present $=1)$

17. Aedeagus preapically $($ slender $=0$, globose $=1)$

18. Apex of aedeagus (acute $=0$, rounded $=1$ )

19. Processes of external parameres (absent $=0$, present $=1)$

20. Base of external parameres (free $=0$, fused $=1$ )

21. External parameres with pores $(a b s e n t=0$, present $=1$ )

22. Hypandrium with claspers $($ absent $=0$, present $=1)$

23. Macrosetae on hypandrium $($ absent $=0$, present $=1$ )

24. Female v1 (absent $=0$, vestigial, fused to clunium $=1$, conspicuous, not fused to clunium $=2$ )

25. Latero-posterior processes of subgenital plate $($ absent $=$ 0 , present $=1$ )
RESULTS

Garcialdretiella n. gen.

http://zoobank.org/4E069D90-93BE-4DB4-853405245A00EDBC

Diagnosis. Belonging in the tribe Graphocaeciliini. Ocelli absent. Veins of forewing with a row of conspicuous setae, except on $\mathrm{Cu}_{2}$. Posterior border of clunium, over the area of the epiproct, with a concave projection; border of clunium, over the area of each paraproct, next to the middle projection, with a group of macrosetae. Male paraprocts with a distinct, elongate, sclerotized anterior process, joined to clunium. Hypandrium with latero-posterior border distinctly thickened, surface setose. Endophallus large, formed by a group of small and big sclerites. Aedeagal arch projected posteriorly in the middle, projection tapered, wide and oval basally. External parameres anteriorly wide, narrowing distally to a blunt end. Related to Acantholachesilla and Dagualachesilla, differing from both in the structure of the clunial projection and in the shape and structure of the aedeagal arch.

Etymology. The generic name is a compound noun, feminine in gender, formed with two last names, Garcia and Aldrete. It is dedicated to Professor Alfonso Neri García Aldrete, a dear and respected teacher of the new generations of psocidologists. His contributions to psocidology are of an immense value.

Type species. Garcialdretiella munchiquensis sp. n.

Garcialdretiella munchiquensis n. sp.Male. (Figs 1-7)

http://zoobank.org/5058F80D-C80A-4B83-8BE87D1DDB764992

Diagnosis. As in generic diagnosis plus the following: male with distal end of abdomen broad, hypandrium with sides and posterior border distinctly thickened, surface setose (Fig. 5). Phallosome broadly triangular (Fig. 6), aedeagal arch projected posteriorly in the middle, the projection tapered, wide and oval basally. Clunial projection wide, concave, with latero-posterior border lobed, posterior margin serrated (Fig. 6). External parameres with a slender posterior projection, aedeagal apex tapered.

Color (in 80\% ethanol). Body light brown to brown (Fig. 7), head and thorax brown; compound eyes black, legs light brown, forewings light brown; hindwings almost hyaline, abdominal sternites and tergites pale yellow (Fig. 7), phallosome brown, clunium brown, apex of aedeagal arch dark brown. Clunial projection dark brown distally; epiproct light brown, with brown lateral area from base to apex; paraprocts light brown, with brown basal process (Fig. 4).

Morphology. As in diagnosis plus the following: Head with vertex slightly concave and above the dorsal margin of compound eyes (Fig. 3), setae and macrosetae as illustrated (Figs. 3 and 7). Compound eyes prominent, with small interommatidial setae. Mx4/Mx2: 1.37. Forewings (Fig. 1), L/W: 2.94; pterostigma elongate, lp/wp: 2.55, wider distally, with setae on the membrane; areola postica broadly triangular, al/ah: 1.65. Hindwings (Fig. 2), 1/w: 3.28. Abdominal sternites and tergites (I-VII) with a row of setae (Fig. 7). Hypandrium strongly convex ventrally (Fig. 7), with abundant setae and macrosetae (Fig. 5). Phallosome (Fig. 6), radular sclerite with small to big sclerites. Paraprocts (Fig. 4) broad, with anterior process long, sclerotized, join- 
ing the clunium; with field of spiculae delimited by rows of macrosetae and setae; sensory fields with 13 trichobothria in basal rosettes. Epiproct long, posteriorly rounded, proximal half covered by the clunial process (Fig. 5)

Measurements. (In microns). FW: 3262, HW: 2475, F: 1060, T: 1675, t1: 585, t2: 190, ctt1: 15, Mx4: 261, f1: 655 , f2: $663, \mathrm{f3}: 490, \mathrm{f} 4: 366, \mathrm{f} 5: 205, \mathrm{f} 6: 200, \mathrm{f} 7: 180, \mathrm{f} 8: 155$, f9: 146, f10: 140, f11: 141, IO: 340, d: 180, D: 230, IO/d:

\subsection{9, PO: 0.78 .}

Type locality. Holotype male. COLOMBIA. Cauca, El Tambo. Cerro Munchique National Natural Park, Km. 65, Road to the Pacific Ocean, $02^{\circ} 42^{\prime} 4.7^{\prime}$ N $: 76^{\circ} 53^{\prime} 21.5^{\prime}$ ' W, 2915 m. 23.VII.2017. J. Panche. Beating shrubs with dead, hanging leaves. Paratypes: 3 males, same data as the holotype. 1 male. Road El Planchón, 02 $41^{\prime} 22.9^{\prime \prime} \mathrm{N}: 76^{\circ}$ 54'6.3" W, 2387 m. 22.VII.2017. J. Panche. Beating shrubs
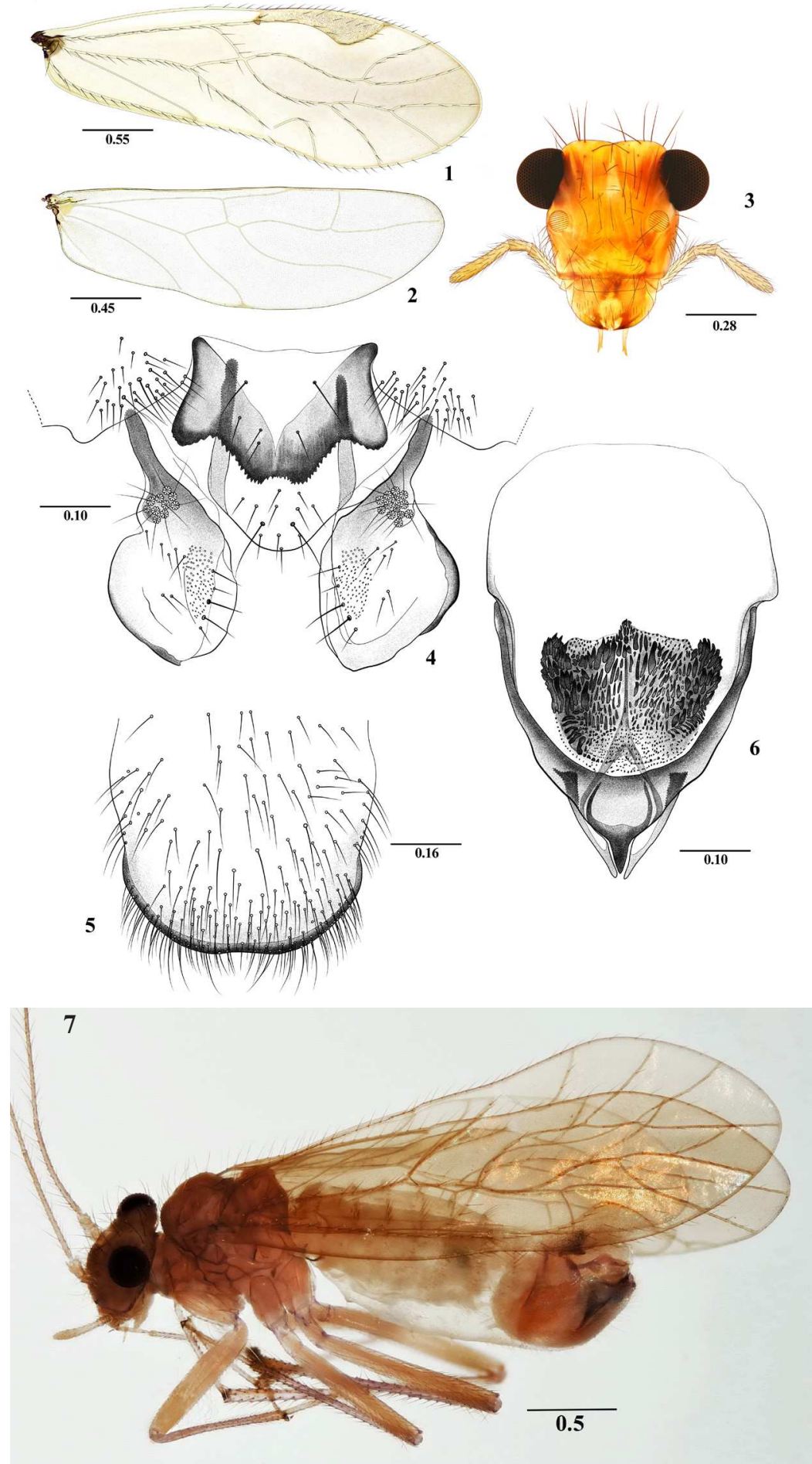

Figures 1-7. Garcialdretiella munchiquensis gen. et sp. n. Male. 1. Forewing. 2. Hindwing. 3. Front view of head. 4. Paraproct, epiproct and clunial projection. 5. Hypandrium. 6. Phallosome, dorsal view. 7. Habitus. Scales in mm. 
with dead, hanging leaves.

Etymology. The specific name refers to Cerro Munchique in the Munchique National Natural Park, where this species was found.

\section{PHYLOGENETIC ANALYSIS}

The implicit enumeration analysis found two most parsimonious trees (MPT) with 38 steps. The strict consensus tree has a consistency index (CI) of 0.796 and a retention index (RI) of 0.667 (Fig. 8). According to our analysis, Acantholachesilla Garcia Aldrete et al. (2014) and Garcialdretiella gen. n. are sister genera, a relationship that is supported by two synapomorphies: Clunial process over the area of the epiproct with serrated posterior edge and presence of macrosetae in the hypandrium, compared to Dagualachesilla Garcia Aldrete et al. (2013) and Dagualachesilloides Garcia Aldrete et al. (2013) (see discussion below).

\section{KEY TO THE GENERA OF GRAPHOCAECILIINI}

(Modified from García Aldrete et al. 2013 b)

1. Ocelli present .. 2

- Ocelli absent (Fig. 3) ... 4

2. Forewing areola postica joined to $\mathrm{M}$ for a short distance ... Anomopsocus Roesler

- Forewing areola postica free from M (Fig. 1) .. 3

3. Aedeagus broad and truncated distally; $v 2+3$ ending as a slender process ... Mesolachesilla Mockford \& Sullivan

- Aedeagus ending in an acuminate process; v2+3 broadly rounded distally ... Graphocaecilius Enderlein

4. Forewing areola postica joined to $\mathrm{M}$ for a short distance Carrejo Anomolachesilla Garcia Aldrete, Gonzalez \&

- Forewing areola postica free from M (Fig. 1) .. 5

5. Phallosome closed anteriorly (Fig. 6), clunium with posterior border variable .. 6

- Phallosome open anteriorly; clunium with one tubular projection between each paraproct and epiproct, and with one broad projection, with a median posterior concavity, over the area of the epiproct .. Cuzcolachesilla Garcia Aldrete

6. Posterior border of clunium, over the area of the epiproct, with a broad, elongated, curved, spatulated posterior projection or slightly thickened (Fig. 4); female subgenital plate posteriorly with a small concavity or with two small projections .. 7

- Posterior border of clunium not thickened, and not projected posteriorly as above; female subgenital plate not as above .. 10

7. Posterior border of clunium, over the area of the epiproct, with an elongated or widened, spatulate posterior projection (Fig. 4) .. 8

- Posterior border of clunium, over the area of the epiproct, slightly thickened, not projected posteriorly

Dagualachesilloides Garcia Aldrete, Gonzalez \& Carrejo

8. Posterior projection of clunium, over the area of the epiproct, broad, elongate, spatulate, with posterior margin curved, wider distally.. Dagualachesilla Garcia Aldrete, Gonzalez \& Carrejo

- Posterior projection of clunium, over the area of the epiproct, elongate or widened, with finely serrated posterior edge (Fig. 4) .. 9

9. Posterior projection of clunium, over the area of the epiproct, almost quadrate and narrow distally, slightly convex dorsally, densely spinose .. Acantholachesilla Garcia Aldrete, Saenz \& Gonzalez

- Posterior projection of clunium, over the area of the epiproct, wide, concave dorsally and with latero-posterior lobes (Fig. 4) .. Garcialdretiella gen. n.

10. Phallosome anteriorly flat; endophallus only with minute denticles .. 11

- Phallosome distinctly stemmed anteriorly, or anteriorly round, slightly extended; endophallus with some minute denticles and some large sclerites .. 12

11. Aedeagus terminating in a pointed or knobbed process; arms of aedeagus ribbon-like, capable of pleat-folding; each arm joining base of phallosome on lateral side of strut to external parameres .. Prolachesilla Mockford \& Sullivan

- Aedeagus forming a broad arch distally; arms of aedeagus stout, joining external parameres on median surfaces of the latter .. Notolachesilla Mockford \& Sullivan

12. Phallosome with distinct anterior stem.. 13

- Phallosome rounded or slightly extended anteriorly .. 14

13. Aedeagus rounded, endophallus with four sclerites, two small and two larges; male clunium with a large triangular projection, flanked by sclerotized rods over the area of the epiproct, also, a sclerotized rod next each paraproct, on outer edge .. Amazolachesilla Garcia Aldrete \& Mockford

- Aedeagus extended posteriorly in the middle; male clunium slightly extended over base of epiproct as a short shelf .. Nanolachesilla Mockford \& Sullivan

14. Aedeagus terminating in a broad knob; male clunium slightly extended over the base of epiproct to form an obtuse concave projection; endophallus with two large, chelate sclerites and many minute denticles .. Antilachesilla Mockford \& Sullivan

- Aedeagus a heavily sclerotized piece, terminating in a broad process bifid at its tip; male clunial projections over the base of paraprocts; epiproct complex. Endophallus with numerous, large chelate sclerites and many minute denticles .. Tricholachesilla Mockford \& Sullivan

\section{DISCUSSION}

The phylogenetic analysis supported a close relationship of Acantholachesilla, Dagualachesilla Garcia Aldrete et al. (2013) Dagualachesilloides Garcia Aldrete et al. (2013) and Garcialdretiella gen. n., based on similarities of the male phallosome, endophallus, hypandrium and paraprocts. The four genera were placed in a well-supported clade with five unambiguous synapomorphies: Ocelli absent; veins Rs and $\mathrm{M}$ of forewing not joined by a crossvein; endophallic sclerites fused in a papillar structure; base of external parameres fused; external parameres without pores. These genera differ mostly by the shape of the clunial projection over the epiproct, the shape of the paraprocts and the presence or absence of macrosetae in the hypandrium. In this analysis, only an unambiguous synapomorphy and two homoplasies support the genus Garcialdretiella, but there are additional characters (not included in the analysis) that are unique and separate the new genus from Acantholachesilla: Posterior 
projection over the area of the epiproct widened, concave dorsally and with latero-posterior lobes (see key above). The distribution of the species here analyzed is another factor contributing evidence that Garcialdretiella is a different genus from the genera already described. Dagualachesilla, Acantholachesilla and Dagualachesilloides are distributed in western Valle del Cauca, in the Chocó biogeographic region, the first two at an elevation of $\sim 500$ meters above sea level (Garcia Aldrete et al. 2014). Dagualachesilla is found in a wider altitude range, between approximately 500-1200 masl, while Dagualachesilloides has been collected between 1687 and 2145 masl (García Aldrete, 2013b). Differently, Garcialdretiella was collected in the Andean region of the Cauca department, at 2387 and 2915 masl, which implies that Garcialdretiella has a potentially different physiology when compared to the other three genera here analyzed. Although the analysis supports Acantholachesilla as sister to Garcialdretiella, we were not able to disentangle how this clade is related to Dagualachesilla and Dagualachesilloides. One of the limitations of this study is that three out of the four genera are monotypic and many of the informative characters used to define the genera behave like autapomorphies. We hope to clarify the relationships between these genera in a publication currently being prepared for the phylogenetic relationships of the genera in the tribe Graphocaeciliini.

\section{ACKNOWLEDGMENTS}

We wish to thank Colciencias for a grant to the authors (Project: "Revisión Taxonómica y Endemismos de los Psócidos (Psocodea: 'Psocoptera') de Parques Naturales de Colombia", Code 1106-659-44236). We are grateful to Jeferson Panche for their invaluable help in field work. We

Recibido: 21 marzo 2020

Aceptado: 16 abril 2020 also thank Juan Iván Sánchez Bernal, Claudia Isabel Acevedo Bueno and Rodrigo Sarria of Munchique National Natural Park, for logistic support and assistance in the area of sampling. RGO and NCG thank Departamento de Biología, Facultad de Ciencias Naturales y Exactas, Universidad del Valle, Colombia, for research support.

\section{LITERATURE CITED}

Felsenstein, J. 1985. Confidence limits on phylogenies: an approach using the bootstrap. Evolution, 39 (4): 783 791.

García Aldrete, A. N. 2012. A new genus of Lachesillidae (Psocoptera) from the Peruvian Amazonia. Zootaxa, 3303: 65-68.

García Aldrete, A. N., González, R. \& Carrejo, N. S. 2013 a. A new genus of Lachesillidae (Psocoptera: Eolachesillinae: Graphocaeciliini) from Colombia. Dugesiana, 19 (2): 91-97.

García Aldrete, A. N., González, R. \& Carrejo, N. S. 2013 b. New genera of Lachesillidae (Psocodea:'Psocoptera': Eolachesillinae: Graphocaeciliini) from Valle del Cauca, Colombia. Zootaxa, 3647 (4): 555-566. DOI: 10.11646/zootaxa.3647.4.5

García Aldrete, A. N., Saenz, O. F. \& González, R. 2014. Acantholachesilla, a new genus of Lachesillidae (Psocoptera: Eolachesillinae: Graphocaeciliini) from Valle del Cauca, Colombia. Zootaxa 3821 (5): 567-574. http://dx.doi.org/10.11646/zootaxa.3821.5.4

García Aldrete, A. N. \& Mockford, E. L. 2011. Amazolachesilla, a new genus of Eolachesillinae (Insecta: Psocodea: 'Psocoptera': Lachesillidae) from Amazonas, Brazil. Acta Amazonica, 41(4): 553-556.

Goloboff, P., Farris, J. \& Nixon, K. 2008. TNT, a free program for phylogenetic analysis. Cladistics, 24 (5): 774786.

Maddison, W. P. \& Maddison, D. R. 2019. Mesquite: a modular system for evolutionary analysis. Version 3.61 http://www.mesquiteproject.org.

Mockford, E. L. \& Sullivan, D. M. 1986. Systematics of the graphocaeciliine psocids with a proposed higher classification of the family Lachesillidae (Psocoptera). Transactions of the American Entomological Society, 112 (1): 1-80.

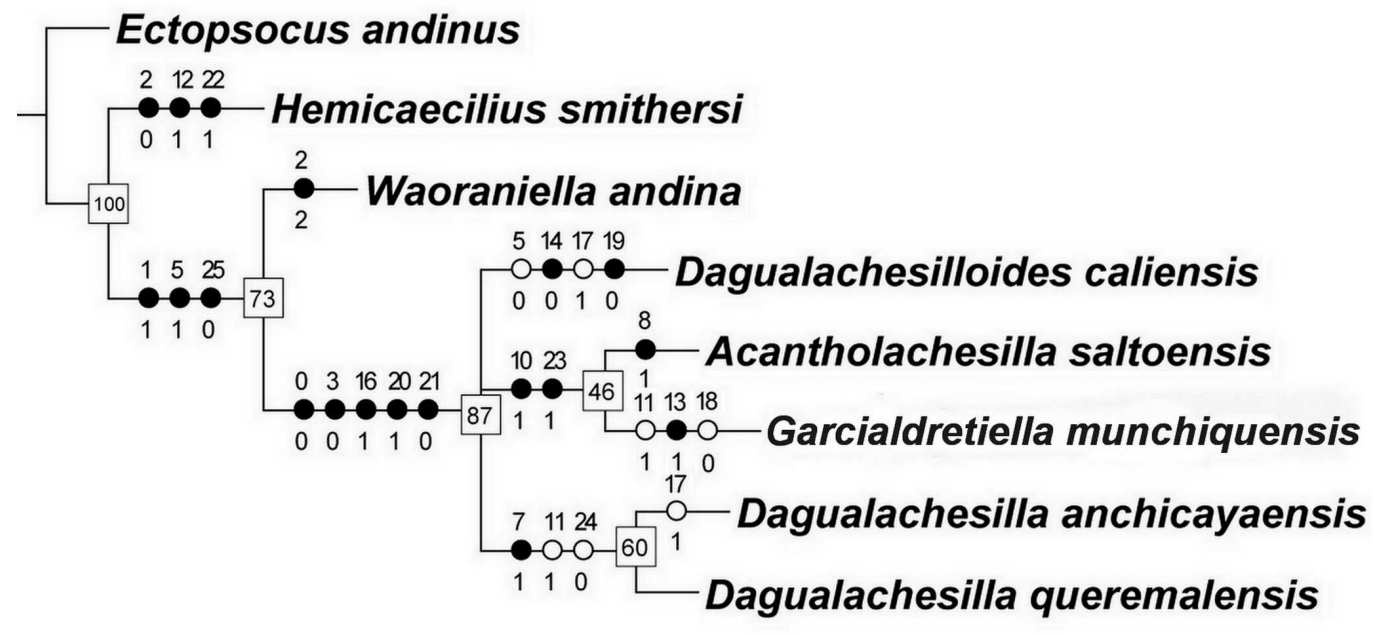

(C) 2020 Universidad de Guadalajara, Dugesiana 27(2): 119-124
Figure 8. Phylogenetic hypothesis for the relationships of Garcialdretiella gen. $\mathrm{n}$. with Acantholachesilla, Dagualachesilla and Dagualachesilloides $($ Length $=38, \mathrm{CI}$ $=0.795, \mathrm{RI}=0.667)$. Numbers in nodes indicate support values for the clades. 


\begin{tabular}{|c|c|c|c|c|c|c|c|c|c|c|c|c|c|c|c|c|c|c|c|c|c|c|c|c|c|c|}
\hline \multirow{3}{*}{ TAXA } & \multicolumn{26}{|c|}{ Character } \\
\hline & 0 & 1 & 2 & 3 & 4 & 5 & 6 & 7 & 8 & 9 & 1 & 1 & 1 & 1 & 1 & 1 & 1 & 1 & 1 & 1 & 2 & 2 & 2 & & 2 & 2 \\
\hline & & & & & & & & & & & 0 & 1 & 2 & 3 & 4 & 5 & 6 & 7 & 8 & 9 & 0 & 1 & 2 & 3 & 4 & 5 \\
\hline Ectopsocus andinus & 1 & 0 & 1 & 1 & 1 & 0 & 0 & ? & ? & ? & ? & 0 & 0 & 0 & 1 & 0 & 0 & 0 & 0 & ? & 0 & 1 & 0 & 0 & 2 & 1 \\
\hline Waoraniella andina & 1 & 1 & 2 & 1 & 1 & 1 & 1 & 2 & 0 & 0 & 0 & 0 & 0 & 0 & 1 & 1 & 0 & 0 & 1 & 1 & 0 & 1 & 0 & 0 & 1 & 0 \\
\hline Hemicaecilius smithersi & 1 & 0 & 0 & 1 & 0 & 0 & 0 & $?$ & ? & ? & ? & 0 & 1 & ? & ? & ? & $?$ & $?$ & $?$ & $?$ & ? & ? & 1 & 0 & 0 & (1) \\
\hline Dagualachesilla anchicayaensis & 0 & 1 & 1 & 0 & 0 & 1 & 2 & 1 & 0 & 0 & 0 & 1 & 0 & 0 & 1 & 1 & 1 & 1 & 1 & 1 & 1 & 0 & 0 & 0 & 0 & 0 \\
\hline Dagualachesilla queremalensis & 0 & 1 & 1 & 0 & 0 & 1 & 2 & 1 & 0 & 0 & 0 & 1 & 0 & 0 & 1 & 1 & 1 & 0 & 1 & 1 & 1 & 0 & 0 & 0 & 0 & 0 \\
\hline Dagualachesilloides caliensis & 0 & 1 & 1 & 0 & 0 & 0 & 1 & 0 & 0 & 1 & 0 & 0 & 0 & 0 & 0 & 1 & 1 & 1 & 1 & 0 & 1 & 0 & 0 & 0 & 1 & 0 \\
\hline Acantholachesilla saltoensis & 0 & 1 & 1 & 0 & 0 & 1 & 2 & 0 & 1 & 1 & 1 & 0 & 0 & 0 & 1 & 1 & 1 & 0 & 1 & 1 & 1 & 0 & 0 & 1 & 1 & 0 \\
\hline Garcialdretiella munchiquensis & 0 & 1 & 1 & 0 & 0 & 1 & 2 & 0 & 0 & 2 & 1 & 1 & 0 & 1 & 1 & 1 & 1 & 0 & 0 & 1 & 1 & 0 & 0 & 1 & ? & 0 \\
\hline
\end{tabular}

